\title{
The role of organized civil society in tobacco control in Latin America and the Caribbean
}

Beatriz Marcet Champagne, PhD, ${ }^{(1)}$ Ernesto Sebrié, MD, MPH, ${ }^{(2)}$ Verónica Schoj, MD. ${ }^{(3)}$

\author{
Marcet Champagne B, Sebrié E, Schoj V. \\ The role of organized civil society in tobacco control \\ in Latin America and the Caribbean. \\ Salud Publica Mex 2010;52 suppl 2:S330-S339.
}

\begin{abstract}
Civil society has been the engine that has permitted many of the accomplishments seen in tobacco control in Latin America and the Caribbean. However, the role of civil society is not clearly understood. Civil society plays five main roles: advocate, coalition builder, provider of evidence-based information, watchdog and service provider. Some of these roles are played weakly by civil society in the region and should be encouraged to support beneficial societal change. Civil society working in tobacco control has evolved over the years to now become more professionalized. The WHO Framework Convention on Tobacco Control and the Bloomberg Initiative to Reduce Tobacco Use have brought about significant change with positive and negative consequences. Strengthening civil society not only supports the tobacco control movement but it provides competencies that may be used in many ways to promote change in democratic societies.
\end{abstract}

Key words: non-governmental organizations; public health advocacy; Framework Convention on Tobacco Control
Marcet Champagne B, Sebrié E, Schoj V.

El papel de la sociedad civil organizada en el control

del tabaco en Latinoamérica y el Caribe

Salud Publica Mex 2010;52 supl 2:S330-S339.

\section{Resumen}

La sociedad civil ha sido el motor que ha permitido muchos logros en el control del tabaco en Latinoamérica y el Caribe. Sin embargo, no se comprende bien el papel que juega. La sociedad civil tiene cinco roles principales: abogar, construir coaliciones, proveer información basada en evidencia, ser perro guardián y proveer servicios. Algunos de estos roles se juegan débilmente y deben ser promovidos para apoyar cambios benéficos en la sociedad. La sociedad civil ha evolucionado a través de los años en el control del tabaco y ahora se ha profesionalizado más. El Convenio Marco para el Control del Tabaco (CMCT) de la OMS y la iniciativa Bloomberg para Reducir el Uso del Tabaco han traído consigo cambios significativos con consecuencias positivas y negativas. El fortalecimiento de la sociedad civil no sólo significa un beneficio para el movimiento del control del tabaco sino que también provee las competencias que sirven de muchas formas para promover el cambio en las sociedades democráticas.

Palabras clave: organizaciones no gubernamentales; abogacía en salud pública; Convenio Marco para el Control del Tabaco

(I) InterAmerican Heart Foundation. Dallas, Texas, USA

(2) Department of Health Behavior, Roswell Park Cancer Institute. Buffalo, New York, USA.

(3) Fundación InterAmericana del Corazón. Buenos Aires, Argentina. 
$\mathrm{C}$ ountries and other jurisdictions in Latin America and the Caribbean (LAC) have achieved great progress in implementing effective tobacco control policies over the last 5 years, mostly due to the international momentum created by the World Health Organization (WHO) Framework Convention on Tobacco Control (FCTC). Notable examples in four tobacco control policy areas include the implementation of $100 \%$ smokefree policies at the national level in Colombia, Guatemala, Panama, Trinidad \& Tobago, and Uruguay, and at the sub-national level in Mexico, Brazil, and Argentina. In addition, Peru and Paraguay are expected to follow in 2010 and Honduras in 2011. Pictorial-based health warning labels have been adopted in Brazil, Colombia, Chile, Panama, Peru, Uruguay, and Venezuela. Bolivia, Paraguay, and Mexico are expected to follow in 2010 and Honduras and Nicaragua in 2011. In 2008, Panama became the first country of the region to completely ban tobacco products advertising, sponsorship and promotion. Colombia will follow suit in 2011. Taxation policies have been implemented with some success in Uruguay, Brazil, Mexico, and Jamaica.

In most of these accomplishments, civil society played a significant role and was frequently the motor that energized other institutions to move the tobacco control agenda forward. In spite of this key role, there is frequent confusion about what civil society is, what its role is and how to facilitate its activity. Even within entities working in tobacco control, many find the actions of civil society too aggressive and confrontational. As civil society efforts frequently involve work behind the scenes, results may merge with those of other institutions and might be not clearly recognized.

This article describes what civil society is and the role it plays in tobacco control; reviews the historical development of civil society in LAC; identifies elements that facilitate or create obstacles for the actions of civil society; and suggests means for strengthening this sector for the benefit of improving tobacco control public policies in the region. Two major events changed the rules of the game for civil society: the adoption of the FCTC and the largest influx of resources to date from the Bloomberg Initiative (BI) to tobacco control. These events are also reviewed. While there is a base of knowledge about civil society and its work, the content of this article relies principally on the experience of the authors and on many LAC leaders who provided their experiences for this effort.

\section{Defining civil society}

Civil society is the sector of society composed of the totality of voluntary civic and social organizations and institutions. It forms the basis of a functioning democratic society. It is distinct from government (regardless of that state's political system) and commercial institutions/ business. ${ }^{1}$ Civil society includes registered charities, non-governmental organizations, community groups, women's organizations, minorities groups, faith-based organizations, professional associations, trades unions, self-help groups, social movements, business associations, coalitions, and advocacy groups. Academic institutions are sometimes included in this sector but as they have different characteristics, for the purpose of this discussion they are not considered part of civil society.

Government and civil society have very clear and distinct characteristics and roles. Government has the power of the state, is responsible for public health, is limited by political changes and might change its priorities with the changing political environment. It may apply large financial resources if there is political will, or may lose those resources without that will. Government employees have to present an official position and risk being fired if not in line with the prevalent politics. Governments also have many official networks such as state or provincial offices.

On the other hand civil society is and should be independent from government and has in theory complete freedom to act. It might have an altruistic mission towards a common good and may be able to have greater consistency in pursue of its mission as is not as influenced by political winds. It may support and pressure government from the outside. It has other networks such as scientific experts or businesses that might not be so available to governments, including expert volunteers. It usually cultivates a strong and independent relation to the media. Further, it may obtain additional funding for a cause.

\section{Roles of civil society}

Civil society plays five main roles: advocate, coalition builder, provider of evidence-based information, watchdog, and service provider. ${ }^{2-4}$ Each of these roles is described below.

As an advocate, civil society promotes a favorable public opinion, supports government actions if favorable to the tobacco control cause, might identify legislative priorities and help develop legislative measures. Usually civil society seeks to portray a powerful, respectable and trustworthy image to support its actions. Model smokefree legislation and letter writing campaigns are examples of this advocacy role. Further, civil society conducts independent research for advocacy purposes such as public opinion polling 
and preparation of white papers. Civil society has an irreplaceable role in advocacy with political decision makers and the media to position relevant health topics in a country's political and public agenda, thus changing the course of health policies.

As a builder of networks, alliances and coalitions, civil society convenes various organizations from many different backgrounds behind a common cause or objective. Examples of this role are smokefree coalitions, general tobacco control alliances and other entities usually organized around a platform to which each organization signs on.

As a provider of evidence-based information, civil society informs policy decisions and frequently translates science for use by policy makers, media and the public. Fact sheets are a means frequently used by civil society to make complex topics such as taxation more accessible to non-experts.

As a watchdog, civil society monitors and reports on the progress of government and other institutions in meeting their commitments and achieving their goals. This role involves conducting independent monitoring and evaluation that might permit unbiased determination of achievement. "Report cards" or "shadow reports" are examples of this watchdog role. So are air quality monitoring studies to determine degree of compliance with smokefree legislation and tobacco advertising monitoring to assess compliance with advertising bans. This role also includes independent research such as to determine health and economic impact of policies.

Finally, civil society often plays a service provider role. It might provide counseling to patients, smoking cessation services, treatment for the poor, and screenings. This service provider role, while important, frequently tends to overshadow its other roles. Providing services is less controversial and fits well with the charitable role considered the main stream of civil society. However, civil society's greatest power comes from its role as advocate, watchdog and provider of evidence-based information. It is these latter roles that make civil society a powerful agent of change.

\section{Historical evolution of the tobacco control movement in Latin America and the Caribbean}

To understand the role of civil society in LAC it is useful to review the historical progression from lone individuals "fighting" tobacco to the more professional movement that is dawning in our region within the context of the WHO FCTC and the Bloomberg Initiative's funding resources.
Tobacco control entrepreneurs (1970s-1990s)

Although there were pioneering efforts in Brazil in the 1970s such as isolated health professionals and academics speaking against tobacco and the National Cancer Association drawing up an action plan against tobacco use, ${ }^{5}$ the tobacco control movement in LAC started in the 1980s with a few individuals taking on the effort in their countries. These LAC tobacco control pioneers include people such as Mario Rigatto and José Rosemberg in Brazil; Carlos Alvarez Herrera, Jorge Pilheu, Herman Schargrodsky and Diego Perazzo in Argentina; Helmut Kasdorf in Uruguay; Luis Pinillos in Peru; Ella Ferguson in Panama; Francisco López Antuñano and Rafael Camacho Solis in Mexico; and Manuel Adrianza in Venezuela. With relatively little infrastructure and resources for tobacco control, they managed to advance their agenda. They were frequently a "voice crying in the desert". Sometimes they had significant impact such as Venezuela's tax increases or Brazil's setting up its National Tobacco Control Program in 1987. Their work was frequently carried out from multiple venues: academia, government and civil society, with roles blurring between them.

\section{Coalición Latinoamericana Coordinadora para el Control del Tabaco (CLACCTA, Latin American Coordinating Coalition on Tobacco Control) (1980s-1990s)}

In the early 1980's through an initiative of the American Cancer Society (ACS) and the Centers for Disease Control and Prevention (CDC), CLACCTA was created and obtained resources from Health Canada, the Pan American Health Organization (PAHO) and other organizations. CLACCTA met annually to discuss tobacco control progress in the region and to define plans. While some countries advanced during this time (e.g., Brazil and Venezuela), in many, tobacco control was limited to awareness activities. In 1992, the $8^{\text {th }}$ World Conference on Tobacco or Health held in Buenos Aires, Argentina, was a highlight of this period. However, it was quickly overshadowed by the Argentinean president's veto of a comprehensive tobacco control law that had been approved by the national congress. ${ }^{6}$ The challenges were major and CLACCTA was not well suited for the social mobilization that would be required. It was dominated by a few individuals--frequently with no institutional backing or authority, lacked focus on policy priorities, lacked capacity for advocacy and coalition building and, most importantly, funders lost trust in the group's ability to promote policy change. By August 2000 at the $11^{\text {th }}$ World Conference on Tobacco or Health held in Chicago, 
members of the CLACCTA network knew there would no longer be funding for their meetings. In Chicago, the group accepted the offer of the InterAmerican Heart Foundation, one of the newer members of CLACCTA, to provide an institutional home and develop an internet network to continue interaction between members.

\section{InterAmerican Heart Foundation (IAHF) (1995 to present)}

In 2002, the IAHF became the Secretariat for efforts to ratify and implement the FCTC in LAC, supported by a Memorandum of Understanding among ACS, Campaign for Tobacco-Free Kids, American Heart Association and American Lung Association, with in-kind support from Heart and Stroke Foundation of Canada and PAHO. Playing mostly a behind the scenes role, IAHF kept the network informal and obtained funding from various sources to support specific advocacy activities in the region. A successful action was the hiring of Dr. Eduardo Bianco as a regional coordinator. In addition to working regionally, he organized civil society in his own country of Uruguay and initiated a process that culminated with Uruguay becoming a model not only in LAC but worldwide in the implementation of the FCTC. From 2000 to today, the IAHF has organized many activities to support ratification and later implementation of the FCTC, all in conjunction with other international and local organizations. These activities included training workshops on advocacy and coalition building, press conferences, earned media campaigns, journalism contests, shadow reports, opinion polling, and regional tobacco control conferences, among others. IAHF supports advocates working in countries to help define strategies and actions, in light of complex and fast changing local situations. As a result of this latter role, IAHF was well positioned to help organize teams of local advocates when there were opportunities to obtain funding from different resources.

During 2007-09 the IAHF opened 3 regional affiliates in Mexico City, Buenos Aires and Kingston, Jamaica, to involve local players more actively. Through these affiliates, IAHF supported the creation of ALIAR, the smokefree environments coalition in Argentina; ALIENTO, the tobacco control coalition in Mexico; an FCTC network in the Caribbean; La Red, a youth advocacy network; and the development of the Central American Coalition for Tobacco Control. In addition, it has collaborated with INWAT (International Women Net Against Tobacco) in the region. Every year since 2002, Aire Vital, a journalism contest, has been held, with winning journalists helping organize subsequent contests.
Framework Convention Alliance (1999 to present)

With the beginning of negotiations towards the adoption of the FCTC in 2000, the many tobacco control organizations worldwide began coalescing into the Framework Convention Alliance (FCA) to ensure an important and critical role for civil society during negotiations, a role that later became enshrined in the Preamble of the FCTC. With the May 2003 approval of this global treaty by the $56^{\text {th }}$ World Health Assembly, the FCA grew and became the convener of all organizations working on the ratification and implementation of the FCTC. ${ }^{7}$ In LAC, it became a significant movement that energized tobacco control and provided much needed training and technical information to advance this cause. Similarly to IAHF, FCA in LAC has focused on advocacy and has conducted workshops for advocates, governments and the media, press conferences, legislative briefings and other events. The FCA in LAC has become the main link to the FCTC Conferences of the Parties (COP), which are formal meetings of the countries that are parties to the treaty, to advance its implementation and monitoring. Thus, FCA supports the region in participating in the development of various guidelines as well as negotiating additional treaties such as the one around illicit trade of tobacco products.

\section{Other significant actors in this region}

Parallel to the action of the FCA and IAHF, there have been others that consistently supported actions in LAC. The ACS has provided small grants to advocates every year since 2000 and has been a key contributor to capacity building. It provides manuals, toolkits, and other materials that are widely used in the region. More recently it has promoted smokefree workplace programs.

The Research for International Tobacco Control (RITC) program with the International Development Research Center (IDRC) has focused its efforts on supporting research that contributes to tobacco control advocacy. This is a Canadian institution, primarily funded by the Canadian Government, whose mission is to help developing countries use science and technology to solve social, economic, and environmental problems. In LAC a research prioritizing effort in 2007 between IDRC and IAHF resulted in identifying strategic priorities that in turn resulted in funding for civil society and academic organizations to conduct economic demand analyses in six countries of the region, evaluating the relationship between tobacco and poverty, and studying the conditions of tobacco growers. IDRC also contributed to creating BILACCTA ("Biblioteca de Investigaciones 
de LAC sobre el Control del Tabaco", a Library on Tobacco Control Research in $\mathrm{LAC}^{8}$ ), an on-line library of published, unpublished and research in progress.

Health Canada supported civil society in LAC via a number of Canadian civil society organizations such as Physicians for Smokefree Canada, Healthbridge, Heart and Stroke Foundation of Canada, and the Canadian Public Health Association. These organizations act as mentors to civil society organizations working in LAC.

Corporate Accountability International (CAI) is an organization with strong activist roots against abuses of corporate power and an ability to mobilize consumer organizations. It helps the region focus on the role of the tobacco industry and how to counteract its arguments and strategies. It showcases the actions of the industry and greatly increases awareness about its interference with tobacco control.

The Pan American Health Organization (PAHO), although principally working via governments, has also had a substantial role actively supporting civil society. Probably its greatest achievement was its early focus on smokefree environments, which set the region civil society organizations on a path to implement smokefree policies. This decision was made by Armando Peruga and Heather Selin at a moment of transition in the PAHO tobacco control program and it laid the foundation for a policy change focus. ${ }^{*}$

\section{Major turning points}

Two major events have significantly influenced the tobacco control movement in LAC. The first was the approval of the FCTC by the World Health Assembly, including the process of negotiation, ratification, and implementation of this first ever public health treaty. The second was the support from the Bloomberg Philanthropies that contributed US\$125 million in 2006 and US\$250 million in 2008 for tobacco control worldwide.

\section{The WHO Framework Convention on Tobacco Control}

The FCTC was approved unanimously by the $56^{\text {th }}$ World Health Assembly in May 2003, entered into force on February 27 2005, and became a major turning point for tobacco control worldwide. Among other measures, the parties to this treaty agreed to raise taxes on tobacco, protect people from secondhand tobacco smoke, ban advertising, promotion and sponsorship,

\footnotetext{
* Personal communication Heather Selin (March 16, 2010).
}

require strong health warnings on tobacco packaging, and provide cessation services. ${ }^{9}$ Highlighting the importance of civil society, the FCTC preamble cites "the special contribution of nongovernmental organizations and other members of civil society [...] to tobacco control efforts nationally and internationally and the vital importance of their participation in national and international tobacco control efforts." ${ }^{\prime 9}$ As elsewhere, the FCTC in LAC served to focus the work of civil society in tobacco control and spawned a more cohesive and effective movement. The FCA helped educate civil society about the treaty so that it would be difficult to find an advocate in LAC that is not familiar with its main clauses or that cannot identify effective policies for tobacco control. Later, the MPOWER report ${ }^{10}$ promoted by WHO Tobacco Free Initiative further helped cement the meaning of the FCTC.

Monitoring efforts around FCTC implementation had the significant effect of strengthening surveillance mechanisms through the Global Tobacco Surveillance System (GTSS). Various reports by WHO/PAHO, FCA and others contributed to improved understanding of the situation. Following the Canadian model, IAHF supported "shadow reports" by civil society in Colombia, Mexico and Peru, resulting in an annual review of the gap between the FCTC requirements and its actual implementation in these countries (Figure 1 and 2).

\section{The Bloomberg Initiative}

In 2006, the Bloomberg (New York City's Mayor) Philanthropies launched the BI to Reduce Tobacco Use in Low and Middle Income countries, which was another major turning point for civil society in LAC. Prior to Bloomberg funding, few people could dedicate themselves to tobacco control in LAC. Most advocates treated tobacco control as a hobby, after seeing patients, teaching classes, or earning a living in some other manner. Tobacco control was dominated by physicians and other health professionals. Without the support of public relation firms, press conferences were less successful. Political mapping was amateurish. Media monitoring was infrequent and less systematic.

The BI has greatly contributed to professionalizing tobacco control in LAC. In priority countries such as Mexico and Brazil, multiple institutions have received financial resources creating a significant mass with specialized roles, e.g., academic institutions, government and civil society each playing specific roles. Much more technical support has become available whether to review proposed legislation, address unconstitutionality challenges, monitor and evaluate tobacco industry 


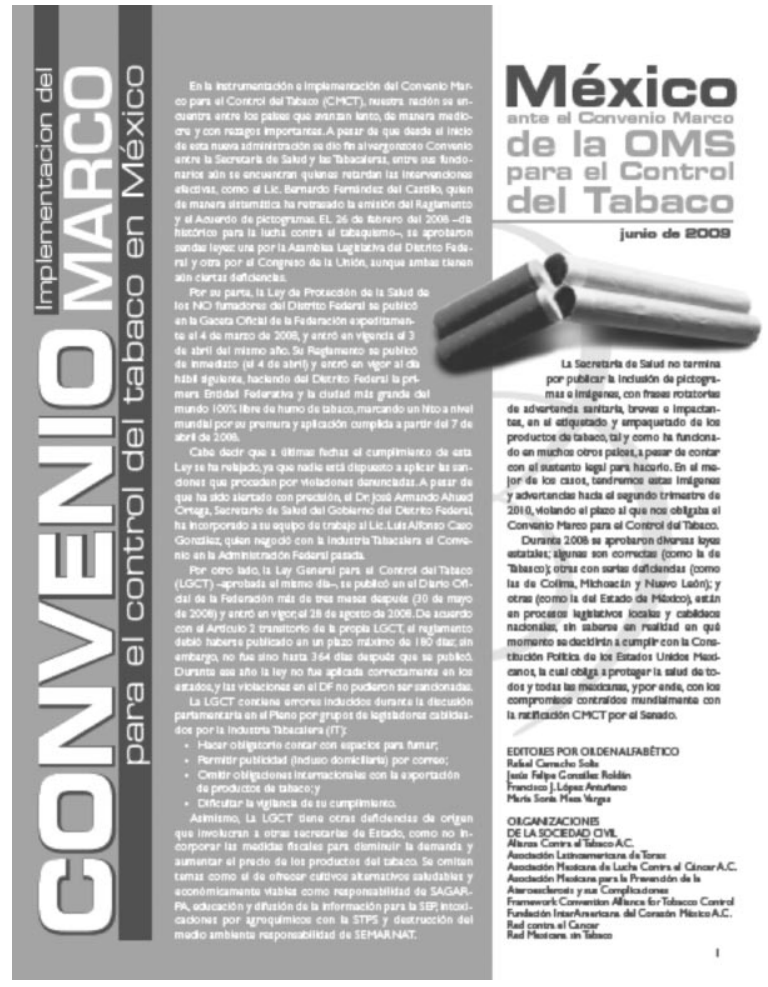

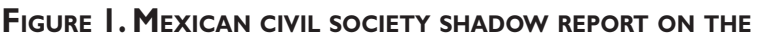
IMPLEMENTATION OF THE FCTC

activity, learn how to monitor air quality, or respond to economic questions.

As part of the BI, the Campaign for Tobacco Free Kids (CTFK) and The Union Against Tuberculosis and Lung Disease (The Union) became grants reviewers, providers of funds and administrators, as well as technical consultants to the region. These two organizations were unknown to LAC in tobacco control prior to the BI but took center stage in the region as the availability of funding attracted many previously uninvolved individuals and organizations. Because of their charters, CTFK may fund advocacy activities while The Union does not, resulting in CTFK greater focus on civil society funding.

With the many benefits of greater funding came also many complications and some perceived injustices. Those charged with distributing BI funding frequently knew little about the region, its culture, politics, or those previously leading the tobacco control movement. Funding criteria were sometimes at odds with reality so that, for example, tobacco control advocates had to rush to identify organizations that might receive funds or form new organizations where none or weak ones

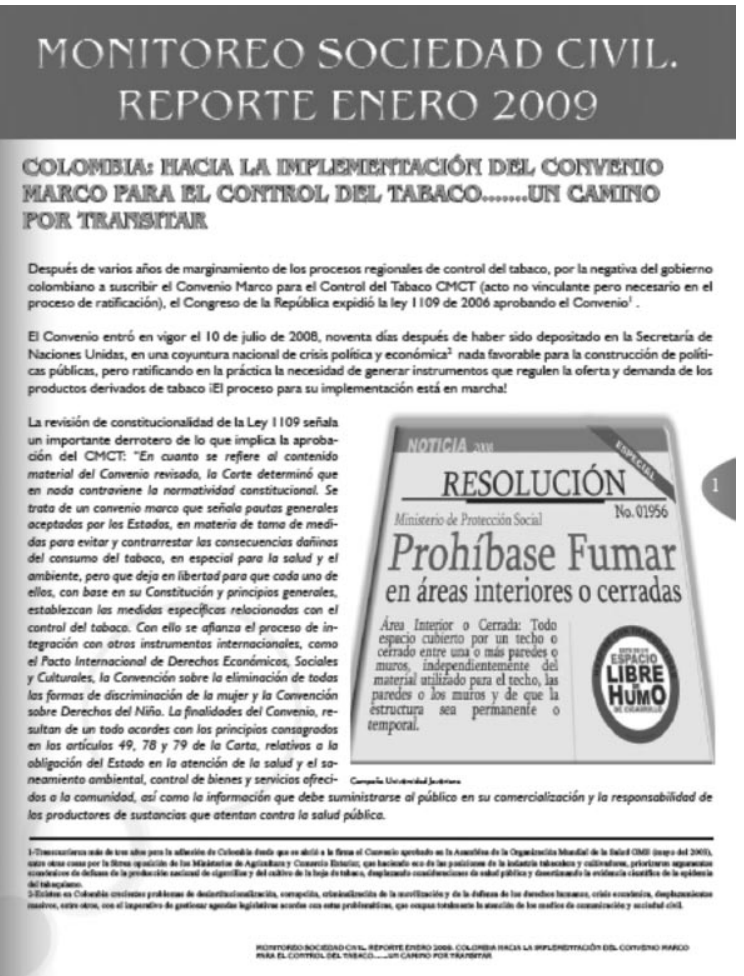

Figure 2. Colombian Civil SOCIETy shadow Report on THE IMPLEMENTATION OF THE FCTC

existed before. Aside from the division between those who were or were not funded, another hierarchical relationship was instituted that further divided the fairly thin ranks of the tobacco control movement now between grantors and grantees. Staffing grantor organizations with technically competent staff has also been a challenge that has at times pitted more junior technical consultants from donor organizations supporting more seasoned and sophisticated grantees. Finally, with funding from BI, other funders wonder about their role and sometimes have decided to take their financial support elsewhere.

A movement that was based on an entrepreneurial spirit and voluntarism has more recently become more bureaucratized. Larger organizations impose complex and restrictive requirements, which may not be appropriate or even feasible for the stage of development of grantee organizations. The competition for funding support has also brought its share of incongruence. Larger international organizations with public relations support compete to tell the story and obtain some credit for accomplishments by grantees. While those on the ground who should actually take most of the 
credit might not have the PR support or be articulate in English.

\section{Civil society achievements}

This section provides some notable examples of the achievements that civil society helped obtained in LAC. Table I shows the principal civil society organizations working on tobacco control in the region. Some countries have successfully organized coalitions either for tobacco control generally or with a specific focus, for example, in smokefree environments.

\section{Argentina}

In spite of significant obstacles, Argentina's civil society has matured and is increasingly working effectively and collaboratively to counteract the powerful lobby of the tobacco industry. Argentina, the second largest producer of tobacco in the region, is one of the few countries in the world and the only one in South America that has yet to ratify the FCTC. All federal tobacco control legislative proposals in the last 40 years have lost parliamentary status without approval. More recently, with the creation of a national program for tobacco control in 2003, the increased participation of state and municipal governments, and the stronger role of civil society, 7 provinces and 20 cities have become 100\% smokefree, covering more than a third of the population of the country or about 15 million people. The smokefree coalition ALIAR, created in 2007 with FIC Argentina as its secretariat, convenes almost 100 organizations to promote smokefree policies through advocacy aimed at political players and the media. ALIAR has also generated scientific evidence of health and economic impact of smokefree policies as well as evaluated compliance, air quality monitoring and public opinion, positioning itself as a credible source of scientific information.

In December 2009, the launching of the Coalition for the Ratification of the FCTC marked another milestone for civil society in this country. With the leadership of all major tobacco control NGOs, more than 300 organizations have joined this coalition that is working closely with the Ministry of Health National Program for Tobacco Control and has constructed a strategic plan that includes advocacy, media campaigns and public events.

\section{Brazil}

Although most of the earlier tobacco control accomplishments in Brazil were the result of government action, the need for strong civil society became obvious
Table I

\section{Main Civil society organizations in Latin America and the Caribbean by country}

Country Examples of civil society organizations

Coalición para la Ratificación de Argentina del CMCT Unión Antitabáquica Argentina (UATA)

Argentina Asociación Argentina de Tabacología (AsAT)

Alianza Libre de Humo - Argentina (ALIAR)

Fundación Inter Americana del Corazón Argentina (FIC Argentina)

\begin{tabular}{ll}
\hline Barbados & Heart \& Stroke Foundation of Barbados \\
\hline Brazil & Aliança de Controle do Tabagismo (ACT Brasil) \\
\hline Chile & Fundación EPES (Educación Popular en Salud) \\
\hline Colombia & $\begin{array}{l}\text { Coalición Colombiana para el Control del Tabaco } \\
\text { Liga Colombiana contra el Cáncer }\end{array}$ \\
\hline Costa Rica & Red Nacional Antitabaco (RENATA) \\
\hline
\end{tabular}

Alianza Ecuatoriana de Lucha Antitabáquica (AELAT) Ecuador Comité Interinstitucional de Lucha Antitabáquica del

Fundación Ecuatoriana de Salud Respiratoria (FESAR)

\begin{tabular}{ll}
\hline \multirow{2}{*}{ El Salvador } & $\begin{array}{l}\text { Asociación de Ex fumadores Salvadoreños (EXFUSAL) } \\
\text { FOSALUD } \\
\text { Defensoría del Consumidor }\end{array}$ \\
\hline \multirow{2}{*}{ Guatemala } & $\begin{array}{l}\text { Consejo Nacional para la Prevención y el Control del } \\
\text { Tabaco en Guatemala (CNCT) }\end{array}$ \\
\hline
\end{tabular}

\begin{tabular}{ll}
\hline Guyana & Guyana Chest Association \\
\hline Honduras & $\begin{array}{l}\text { Alianza Hondureña para el Control del Tabaco } \\
\text { Acción para la Promoción de Ambientes Libres de } \\
\text { Tabaco (APALTA) }\end{array}$ \\
\hline \multirow{3}{*}{ Jamaica } & $\begin{array}{l}\text { Jamaica Coalition for Tobacco Control } \\
\text { The Heart Foundation of Jamaica } \\
\text { InterAmerican Heart Foundation Caribbean }\end{array}$ \\
& ALIENTO \\
Mexico & Alianza Contra el Tabaco A.C. (ACTA) \\
& Fundación InterAmericana del Corazón México A.C. \\
& (FIC Mexico) \\
& CODICE
\end{tabular}

\begin{tabular}{ll}
\hline Nicaragua & Consejo Nacional Antitabaco Nicaragua \\
\hline Panama & $\begin{array}{l}\text { Coalición Panameña para el Control del Tabaco } \\
\text { (COPACET) }\end{array}$ \\
\hline Peru & $\begin{array}{l}\text { Comisión Nacional Permanente de Lucha Antitabáquica } \\
\text { (COLAT) } \\
\text { Centro de Información y Educación para la Prevención } \\
\text { del Abuso de Drogas (CEDRO) }\end{array}$ \\
\hline
\end{tabular}

Trinidad \& Tobago The Trinidad and Tobago Cancer Society

Centro de Investigación de la Epidemia de Tabaquismo

$\begin{array}{ll}\text { Uruguay } & \text { (CIET Uruguay) } \\ \text { Sindicato Médico del Uruguay (SMU) }\end{array}$

Federación Médica del Interior (FEMI)

Venezuela Fundación Venezolana del Corazón 
when political changes threatened to undo those very accomplishments. Throughout the process of FCTC ratification, civil society was active but fragmented. It was not until 2006, with the support of the Canadian International Development Agency (CIDA) and Healthbridge and later with the influx of BI financial support that civil society, under the ACT Brazil coalition, became the strong, capable and effective organization it is today. Its principal accomplishment over the last several years centers on the enactment of 100\% smokefree legislation in the States of São Paulo, Parana, Amazonas, Rondonia, Romaima, Paraiba, and Rio de Janeiro, as well as numerous cities and municipalities. The role of civil society includes also promoting the implementation of the law and compliance monitoring.

In addition, civil society has taken on monitoring the implementation of the FCTC since 2006, which includes preparation of shadow reports to clearly delineate gaps in implementation. It has also had strong influence in advancing other FCTC measures such as crop substitution, prohibition of advertising, promotion and sponsorship of tobacco products, tax increases, illicit trade, as well as participating in international efforts as part of FCA and contributing technical expertise to other countries. ${ }^{*} 11$

\section{Colombia}

The most important accomplishment in tobacco control in Colombia, where civil society had a key role, was the approval of Law 1335 in June 2009. This national tobacco control legislation established, among other measures, 100\% smokefree indoor workplaces and public places, ban of advertisement, promotion and sponsorship of tobacco products, and the adoption of pictorial warning labels. Civil society coalesced into the Colombian Coalition for Tobacco Control in 2008 and led the efforts towards strong federal legislation, coordinating the following activities: political pressure on legislators to amend the original proposal that was not in line with the FCTC, obtaining 23 amendments that finally adequately controlled demand and supply of tobacco products; preparation of printed materials to support advocacy efforts with decision makers and the media; denouncement to the media and the public the actions of the tobacco industry and its allies to interfere; support for the Undersecretary of Health, a main ally, who had drafted Ministerial Resolution No 1956 in 2008 declaring all indoor spaces $100 \%$ smokefree and who,

* Personal Communications Paula Johns and Mônica Andreis (March, 2010). along the process of enacting Law 1335 , had shown great commitment to tobacco control; societal mobilization with public events; participation in all steps necessary for enactment of the law; media advocacy; monitoring by civil society via a shadow report; a legal analysis to establish the constitutional framework for the proposed law; public opinion poll to establish support for smokefree environments; and coordination with international organizations supporting this effort, principally FCA, IAHF, CTFK, PAHO and CAI.

Medical societies participated, providing supporting materials. In the case of the Colombian Society of Cardiology, its strong pronouncements in Congress and through the media had a significant role in the final approval of the law. This society also conducted public opinion polls evaluating social acceptability of smokefree environments. The media, which in the previous 20 failed attempts to approve comprehensive tobacco control had sided with the tobacco industry or had remained neutral, were decidedly in favor of the FCTC and its implementation. ASOBARES, a private organization that represents about $12 \%$ of bars in the city of Bogota, supported the 2008 Ministerial Resolution for smokefree environments, which set the stage for the 2009 law. ${ }^{*}$

\section{Mexico}

Over the past few years civil society has developed greatly in Mexico. It was civil society that denounced in 2006 the agreement of the Ministry of Health with the tobacco industry. It was also civil society that worked with Mexico City's Legislative Assembly in 2007-08 to obtain a $100 \%$ smokefree law. More recently, it pressured government to speed up the development of pictorial warning labels that would be appearing in September 2010. Civil society was also heavily involved in the development of the 2008 General Law for Tobacco Control and its regulation as well as the 2009 meager tax increase. Both efforts fell short of what was desired, yet they showed the increased strength of this sector.

\section{Uruguay}

Even though there have been many excellent government actors, not the least of them former President Dr Tabaré Vázquez, none of Uruguay's many tobacco control achievements would have been possible without the social mobilization from civil society represented by the Centro de Investigación para la Epidemia del

*Personal communication Yul Francisco Dorado (March 17, 2010). 
Tabaquismo (CIET, Center for Research on the Tobacco Epidemic), and accompanied by the Uruguayan Medical Union and the Medical Federation of the Interior. Civil society identified may champions in different aspects of tobacco control that have become experts and consultants to LAC.*

\section{Other examples}

Bloomberg funding was instrumental in organizing civil society in 4 Caribbean countries around developing strong warning labels for CARICOM countries. The Trinidad \& Tobago Cancer Society was a main actor in the approval of the 2009 comprehensive tobacco control legislation in that country. ${ }^{\ddagger}$ Civil society also had a main role to play in smokefree legislation, making Guatemala and Panama the first two countries of Central America that are $100 \%$ smokefree. In the case of Guatemala, civil society played a pivotal role in defending the law in the Supreme Court against the tobacco industry that claimed unconstitutionality of the law. ${ }^{\mathrm{s}}$

\section{Facilitators and obstacles to the action of civil society}

Civil society faces challenges everywhere in the world but particularly in this region where the development of the "third sector" is embryonic. Some of the challenges are the need to bring together diverse social actors into networks and coalitions, obtaining resources that guarantee sustainability long term and avoiding conflicts of interests that could mar its image.

Civil society is in a good position to be an "honest broker" to bring together various interests to coalesce into networks and coalitions. It can facilitate cooperation and interaction and join various efforts among actors. In spite of some of the difficulties brought about by the professionalization of the tobacco control movement, professionalization needs to continue and expand, without excluding voluntarism. Advocates require specialized training and their role can no longer be treated as a hobby. Capacity building is also essential to strengthening this sector. Finally, the appropriate management of conflicts of interest is a key area for civil society action. Numerous civil society organizations in our region have received, and continue to receive, funding from the tobacco industry without appropriate

* Personal Communication Eduardo Bianco (March, 2010).

* Personal Communication Dominique Monteil (March, 2010).

$\S$ Personal Communications Amando Chavarría Samayoa and Dora Oliva (March, 2010). social sanctions for the contradictory nature of these relationships. For example, in spite of its ties to tobacco interests, the CARSO Institute of Mexico is providing funds for health promotion throughout the region. Other funders that also represent possible conflicts of interest, although less evident than the tobacco industry, include companies producing unhealthy foods and pharmaceutical companies, among others. Conflicts of interest may diminish civil society's public image and legitimacy, elements that are important to guard if we want to continue to be effective.

\section{Strengthening civil society in LAC}

The changes that have occurred in recent years in the tobacco control movement in LAC have been many. Without a doubt, the impetus from the FCTC and the resources from $\mathrm{BI}$ have strengthened civil society. They have raised the level of staff competence, increased the number of persons and organizations professionally dedicated to tobacco control, and supported many recent achievements. However, the growth is uneven, with questionable sustainability. In some instances these changes have meant the weakening of original civil society networks to be replaced by others. It has also meant the proliferation of new organizations and networks, which may not be sustainable in the long term. Well-funded, more powerful, frequently foreign organizations have now much influence but, again, it is unclear if they would remain if resources were to be scarce again. It is probably sustainable native networks that can function long term with limited resources that might provide the best insurance for the future.

The LAC region has the good fortune of having two distinct regions each with the same or similar culture, language and history that has facilitated the interaction among its various countries. One is Latin America and the other is the English-speaking Caribbean. In Latin America this is frequently expressed as feelings of "brotherhood" and "sisterhood." While in other regions it might be impossible to work at a supra national level, in LAC it is possible and for some functions, highly desirable. Thus, capacity building, planning and recruitment of talent might be done well regionally, mindful of the primacy of national and local actions. Such integrated efforts strengthen civil society. Indeed such joint action is necessary to counter the strong influence of the transnational tobacco industry in our region.

Finally, civil society, more so than academic and government organizations, are frequently financially fragile. Earmarking tobacco taxes for civil society's efforts in tobacco control is sometimes suggested as a means for long-term sustainability of this sector. 
However, this funding mechanism seems politically unrealistic. Also not immediately viable are calls for fund raising such as carried out by ACS. If not from major donors, where will the resources for sustaining a drawn out effort to implement the FCTC come from? It is a question that has not been well answered yet.

\section{Conclusion}

In spite of the many weaknesses and obstacles experienced by civil society in tobacco control, it is still at the forefront of chronic disease prevention when compared to efforts to improve diets and increase physical activity. The tobacco control movement is more highly focused and strongly competent in advocacy and coalition building, skills that are highly desirable to those working to reduce other risk factors for chronic diseases. While we might learn from other successful movements such as HIV, we have much to contribute to newly developing movements.

Civil society in the LAC region is still far from meeting its potential whether it is in the tobacco control movement or reducing dietary salt. A strong civil society is a sign of a healthy democracy and it empowers the public to organize to seek to improve quality of life of everyone. The role of civil society should be encouraged and strengthen to provide the motor and direction for successful social change in this region.

\section{Acknowledgements}

Dr Ernesto Sebrié was supported by the Flight Attendant Medical Research Institute (FAMRI).

The authors would like to thank the many people working on tobacco control in Latin America and the Caribbean who provided information for this article (in alphabetical order): Mônica Andreis (Brazil), Eduardo Bianco (Uruguay), Amando Chavarría Samayoa (Guatemala). Yul Francisco Dorado (Colombia), Paula Johns (Brazil), Katie Kemper (USA), Guillermo Martínez (Colombia), Adriana Menéndez (Uruguay), Dominique Monteil (Trinidad \& Tobago), Manuel Nogales Mendoza (Argentina), Juan Nuñez (Mexico),
Dora Oliva (Guatemala), Jessica Rodríguez (Honduras), Ernesto F. Ruíz (Argentina), Laura Salgado (Honduras), Manuel de Jesús Sánchez-Berríos (Nicaragua), Heather Selin (USA), Javier Valenzuela (USA), Dawn Williams (Jamaica), and Gustavo Zabert (Argentina).

\section{Declaration of conflicts of interest}

We declare that we have no conflicts of interest.

\section{References}

I. Center for Civil Society, London School of Economics and Political Science. [Accessed on: 2010,April 5].Available from: http://www.lse.ac.uk/ collections/CCS/what_is_civil_society.htm

2.American Cancer Society. Guide 2. Strategy Planning for Tobacco Control Movement Building. [Accessed on: 2010,April 2]. Available from: http://www.strategyguides.globalink.org/

3. American Cancer Society Guide 3. Enacting strong smoke-free laws: The advocate's guide to legislative strategies. July, 2006. [Accessed on: 2010 March 20].Available from: http://www.cancer.org/downloads/AA/ Legislative_Strategies.pdf

4.World Health Organization. Stop the global epidemic of chronic disease: A practical guide to successful advocacy. Geneva,WHO, 2006. [Accessed on: 2010 March 20]. Available from: http://www.who.int/chp/advocacy/en/ 5. da Costa LM \& Goldfarb S. Government Leadership in Tobacco Control: Brazil's experience. In: de Beyer J \& Waverley Brigden L (eds). Tobacco Control Policy: Strategies Successes \& Setbacks. Washington DC, World Bank \& IDRC/RITC, 2003: 38-70. [Accessed on: I0 May, 20I0]. Available from: http://wwwl.worldbank.org/tobacco/pdf/2850-FM.pdf 6. Sebrié EM. Tobacco industry successfully prevented tobacco control legislation in Argentina. Tobacco Control 2005; I4:e2 doi: 10.1 I36/ tc.2005.0I II30. [Accessed on: 2010 March 20].Available from: http:// tobaccocontrol.bmj.com/content//4/5/e2.full.pdf

7. Mamudu HM, Glantz SA. Civil society and the negotiation of the Framework Convention on Tobacco Control. Glob Public Health 2009; 4(2): 150-168.

8. InterAmerican Heart Foundation. [Accessed on: 2010 March 20]. Available from: http://www.interamericanadelcorazon.org/?lang=eng 9.WHO. Framework Convention on Tobacco Control. Geneva,WHO, 2003, updated reprint 2004, 2005. [Accessed on: 2010 February 10]. Available from: http://whqlibdoc.who.int/publications/2003/924I59/0I3.pdf 10.World Health Organization. MPOWER:A Policy Package to Reverse the Tobacco Epidemic. Geneva,WHO, 2008. [Accessed on: 2010 March 10]. Available from: http://www.who.int/tobacco/mpower/mpower_english.pdf II.Aliança de Controle do Tabagismo. [Accessed on: 2010 March I0]. Available from: http://actbr.org.br/ 